inOfedia $\quad \begin{aligned} & \text { InMedia } \\ & \text { The French Journal of Media Studies }\end{aligned}$

$4 \mid 2013$

Exploring War Memories in American Documentaries

John Mullen, 'The show must go on!' La Chanson populaire en Grande-Bretagne pendant la Grande Guerre, 1914-1918

Paris: L'Harmattan, collection “L'Aire Anglophone", 2012, 287 pages

\title{
Yann Béliard
}

\section{(Q) OpenEdition}

Electronic version

URL: http://journals.openedition.org/inmedia/706

DOI: $10.4000 /$ inmedia.706

ISSN: 2259-4728

Publisher

Center for Research on the English-Speaking World (CREW)

\section{Electronic reference}

Yann Béliard, « John Mullen, 'The show must go on!' La Chanson populaire en Grande-Bretagne pendant la Grande Guerre, 1914-1918 », InMedia [Online], 4 | 2013, Online since 12 November 2013, connection on 24 September 2020. URL : http://journals.openedition.org/inmedia/706 ; DOI : https://doi.org/ 10.4000/inmedia.706

This text was automatically generated on 24 September 2020

(c) InMedia 


\section{John Mullen, 'The show must go on!' La Chanson populaire en Grande-Bretagne pendant la Grande Guerre, 1914-1918}

Paris: L'Harmattan, collection “L'Aire Anglophone”, 2012, 287 pages

Yann Béliard

\section{REFERENCES}

John Mullen, 'The show must go on!' La Chanson populaire en Grande-Bretagne pendant la Grande Guerre, 1914-1918, Paris: L'Harmattan, collection “L'Aire Anglophone”, 2012, 287 pages. 
On 30-31 August 2014, an international conference entitled 'The Music of War: 1914-1918' will be held at the British Library to mark the centenary of the outbreak of the First World War. The call for papers published by convenors Jane Angell and Rachel Moore (Royal Holloway, University of London) reads as the perfect introduction for the book under review: “ In recent years there has been a welcome increase in scholarly attention to musical activity during the First World War, and this has begun to reveal the multiple and complex roles of music during the conflict. For civilians and soldiers alike, music of all kinds played a central part in the battle, whether as entertainment, as a powerful means to boost morale, as a vehicle of government propaganda, as a therapeutic tool, or as part of commemoration rituals." John Mullen's

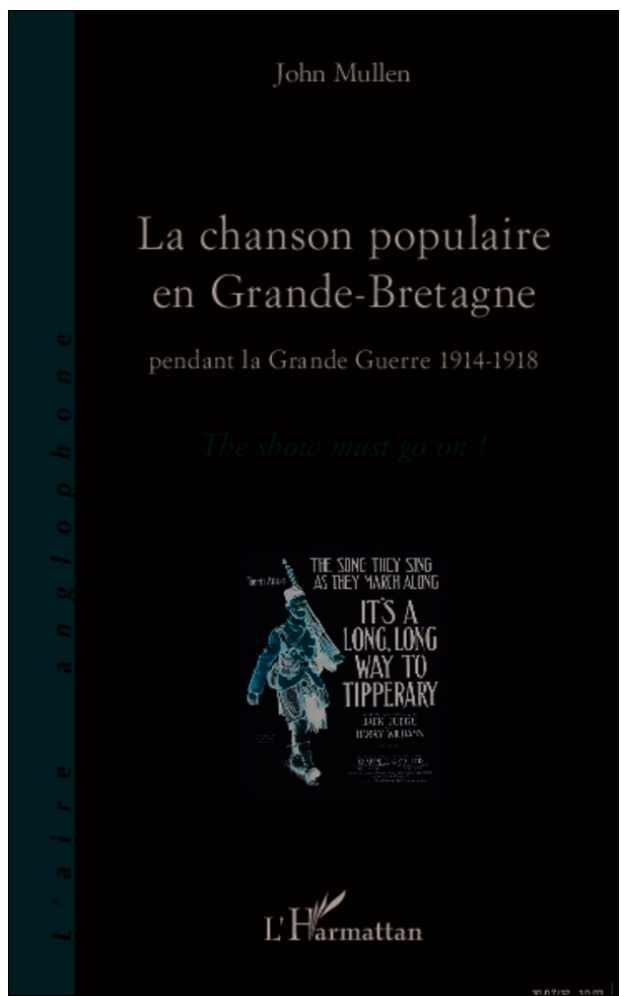
The Show Must Go On! is indeed a fascinating reflection of and contribution to that growing field of study.

A senior lecturer in British studies at UPEC (Université Paris Est Créteil Val de Marne), John Mullen is the one and only French scholar to have published extensively on the topic of popular music in Great Britain during the Great War, mostly in the French academic press - the only other French researcher in the British music-hall industry being Angèle David-Guillou (Université Paris 4), who is currently completing a muchexpected doctoral thesis on musicians' unions in the Edwardian age, under the supervision of Professor Fabrice Bensimon. Mullen's study, informed by his concern for all forms of popular protest in the long nineteenth century, stands at the crossroads of two important streams: the ongoing rediscovery of the First World War "from below" (as embodied in France by historians Nicolas Offenstadt or Rémy Cazals); and the emergence of leisure as a legitimate object for historical research (an option defended and illustrated, among many others on the French side of the English Channel, by Emmanuel Roudaut).

The book is composed of eight chapters - in fact six if one excludes the much shorter introduction and conclusion -, four of which terminate with the portrait of a music hall star (in order of appearance: Harry Lauder, Vesta Tilley, Marie Lloyd and Harry Champion). It also includes statistical tables showing what themes were the most frequent in the wartime commercial and non-commercial song production; a political, military and cultural timeline extending from January 1914 to December 1918; and a ten-page long list of the songs mentioned in the book. As the introduction emphasises, the book sums up months of research in the pages of the national and specialised press - in particular The Performer and The Encore. The topic is approached thematically (chapter two explores the economic structures of the music hall, chapter three the mosaic of genres) without neglecting the evolution in the content of the songs as the 
war dragged on (chapter four). Of the last three chapters, which are all utterly unputdownable (chapter five deals with the representation of women and chapter six with that of the war), the final one (chapter seven) is to be praised more highly for its evocation of the songs conceived outside of the music hall. The ambivalent use of church hymns is well underlined: while so many were meant to support the war effort, the fact that the tunes were universal made it easy to transform them into tools for fraternisation with 'the enemy' during the first winters on the front. Poignant passages are devoted to the songs produced by the Tommies themselves, to their bitter sense of humour ("If you're looking for the general, I know where he is...") and to a rejection of the hierarchy that was not so plain inside the French or German armies.

As a book written for francophone readers belonging to the general public, The Show Must Go On! reaches its target beautifully: it allows the French honnête homme to access, in a pleasant and ever entertaining way, the results of the inquiries that have been led over the past years into the complexities of popular music during the Great War. The web link indications are useful, the sheer quantity of material studied is impressive (more than one thousand songs altogether), the insistence on the economic dimension of cultural productions is welcome. The author's empathy for the common people also stands out as one of the book's crucial qualities. Following Bernard Porter's and Andrew Thompson's warnings about the relativity of domestic imperialism, Mullen refuses to take the public's jingoism for granted and gives due recognition to the dissenting power of song-writing and song-performing in the trenches. The same personal attention to the oppressed sections of British society accounts for the important place given by the author to the key dimensions of race and gender. Unless they are put off rather than charmed by the occasional anglicisme, French readers will undoubtedly find plenty to appreciate in Mullen's synthesis.

Whether the book is destined to become compulsory reading for academics, be they musicologists or cultural historians, or the classic handbook for students specialising in history or cultural studies is yet another question. For reasons that are mostly due, one guesses, to the editorial constraints weighing on the author, The Show Must Go On! is at times frustrating. The reader is provided neither with an index nor with a bibliography and the summary is incomplete, as it does not include the headings of the numerous subparts. The biographical vignettes, however colourful, offer little new information: instead of limiting his choice to four of the most successful performers of the period, the author would have stimulated the specialist's curiosity if he had selected more obscure artists, with careers more specifically linked to the wartime context. A small factual mistake spotted on page 41: Board of Trade arbitrator George Ranken Askwith, who was called to intervene in the music industry troubles, just as he was in the mining or shipping industries, was not raised to the peerage until 1920, so he was not "Lord Askwith" during the Great Labour Unrest of 1910-1914 nor during the post-1916 militant revival.

Possibly the biggest source of irritation for the reader is simply caused by the author's (or more plausibly the editor's) decision to systematically translate the words of the songs into French, without presenting the original text in the footnotes. Though the lyrics have been carefully and indeed rather cleverly transposed from one language into the other, the phonetic - and poetic - dimension of the songs is therefore lost in translation. Even a French reader with limited mastering of Shakespeare's idiom would surely have appreciated a taste of 'the real thing'; and that absence can only be 
partially compensated by the consulting of the video and audio online resources referred to in the book. Would 2014 not be the perfect timing for a translation of Mullen's work into English, and its publication in a deluxe edition comprising a larger array of illustrations and - more importantly still - a CD-box? Should such a dream come true, it would probably make sense to change two elements on the cover: both the light-hearted title ("The show must go on!") and the consensual picture ("The song they sing as they march along: it's a long, long way to Tipperary") might be swapped for more equivocal ones, espousing Mullen's fundamental option: to complexify traditional visions of patriotic unanimity and present a more nuanced analysis than John Brophy and Eric Partridge (The Long Trail - What the British Soldier Sang and Said in the Great War of 1914-1918, London: André Deutsch, 1965).

All in all, there is much to admire in John Mullen's book and its very limitations can be seen as appealing. Arguably, the scholar in search of a state of the art theoretical framework or of an in-depth historiographical overview may be disappointed: the book's vocation is clearly not to subsume Peter Bailey's Music Hall: the Business of Pleasure (Milton Keynes: Open University Press, 1986). But it is precisely that modesty which makes Mullen's study accessible and enjoyable for the greatest number. One may deplore the overwhelming place occupied by London in the enquiry: what about Cardiff and Glasgow, or Liverpool and Hull? On the other hand, when a book leaves you wanting to know more - about the shape of wartime music in Ireland or in the Dominions, for example -, it is generally the sign that the author has more than satisfactorily reached his aim: not only to share his knowledge but to open new perspectives.

To conclude this review, I would like to quote once again from the 'Music of War' conference webpage: "From the sound of artillery to the drone of Zeppelins, those living through the First World War were only too familiar with the sounds of war, whether on the home or fighting fronts. These ominous sounds of death and destruction formed a backdrop to the alternative sounds of war: music-making. (...) The forthcoming centenary of the war is a timely opportunity to reconsider the fundamental role of music and musicians during the exceptional circumstances of 1914-1918." Published two years ahead of the British Library event, John Mullen's rich and lively study does exactly that. And though I am not $100 \%$ sure he would approve of the following suggestion, why not read it alongside John Major's My Old Man: A Personal History of Music Hall (London: HarperCollins, 2012)? And tant pis (too bad) for the speakers of French, or for those who only wish to hear one side of the story.

\section{AUTHOR}

\section{YANN BÉLIARD}

Université Sorbonne Nouvelle, Paris 3 